\title{
\begin{tabular}{l|l} 
MitTraries & DSpace@MIT
\end{tabular}
}

\author{
MIT Open Access Articles
}

\section{Predicting Protein-Polymer Block Copolymer Self-Assembly from Protein Properties}

The MIT Faculty has made this article openly available. Please share how this access benefits you. Your story matters.

Citation: Huang, Aaron et al. "Predicting Protein-Polymer Block Copolymer Self-Assembly from Protein Properties." Biomacromolecules (September 2019): 9b000768 (c) 2019 American Chemical Society

As Published: http://dx.doi.org/10.1021/acs.biomac.9b00768

Publisher: American Chemical Society (ACS)

Persistent URL: https://hdl.handle.net/1721.1/122285

Version: Final published version: final published article, as it appeared in a journal, conference proceedings, or other formally published context

Terms of use: Creative Commons Attribution-NonCommercial-NoDerivs License 


\title{
Predicting Protein-Polymer Block Copolymer Self-Assembly from Protein Properties
}

\author{
Aaron Huang, Justin M. Paloni, Amy Wang, Allie C. Obermeyer, ${ }^{\circledR}$ Hursh V. Sureka, Helen Yao, ${ }^{\odot}$ \\ and Bradley D. Olsen*०
}

Department of Chemical Engineering, Massachusetts Institute of Technology, 77 Massachusetts Avenue, Cambridge, Massachusetts 02139, United States

\section{Supporting Information}

\begin{abstract}
Protein-polymer bioconjugate self-assembly has attracted a great deal of attention as a method to fabricate protein nanomaterials in solution and the solid state. To identify protein properties that affect phase behavior in protein-polymer block copolymers, a library of 15 unique protein- $b$-poly $(N$-isopropylacrylamide) (PNIPAM) copolymers comprising 11 different proteins was compiled and

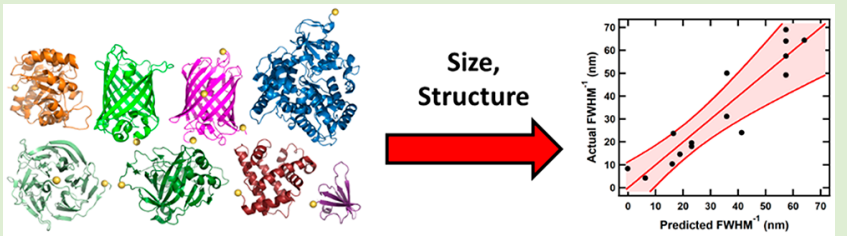
analyzed. Many attributes of phase behavior are found to be similar among all studied bioconjugates regardless of protein properties, such as formation of micellar phases at high temperature and low concentration, lamellar ordering with increasing temperature, and disordering at high concentration, but several key protein-dependent trends are also observed. In particular, hexagonal phases are only observed for proteins within the molar mass range $20-36 \mathrm{kDa}$, where ordering quality is also significantly enhanced. While ordering is generally found to improve with increasing molecular weight outside of this range, most large bioconjugates exhibited weaker than predicted assembly, which is attributed to chain entanglement with increasing polymer molecular weight. Additionally, order-disorder transition boundaries are found to be largely uncorrelated to protein size and quality of ordering. However, the primary finding is that bioconjugate ordering can be accurately predicted using only protein molecular weight and percentage of residues contained within $\beta$ sheets. This model provides a basis for designing protein-PNIPAM bioconjugates that exhibit well-defined self-assembly and a modeling framework that can generalize to other bioconjugate chemistries.
\end{abstract}

\section{INTRODUCTION}

In nature, enzymes have developed as powerful and efficient biocatalysts capable of performing reactions under mild conditions with high activity, selectivity, and specificity. ${ }^{1}$ These traits make them attractive prospects for application in industrial catalysis and sensing. For example, enzymes have proven effective in addressing challenges in a variety of fields including energy generation applications such as fuel catalysis $^{2,3}$ and light harvesting, ${ }^{4}$ environmental applications such as waste treatment ${ }^{5,6}$ and pollutant remediation, ${ }^{7,8}$ or medical applications such as glucose detection ${ }^{9,10}$ and highthroughput immunoassays. ${ }^{11}$ Other globular proteins, such as the fluorescent proteins enhanced green fluorescent protein (EGFP) and monomeric Cherry (mCherry), have even been used in the gain media in optofluidic and solid-state lasers. ${ }^{12,13}$ However, enzymes and other globular proteins suffer from limitations in processability and stability that complicate their use in industrial applications, where biocatalysts should be heterogeneous to allow for separation and reuse of the material. ${ }^{14}$ The globular proteins utilized in these applications must retain good activity, selectivity, and stability in conditions that may stray quite far from physiological environments, settings in which most proteins lose activity or completely denature.
One important solution to address these limitations is immobilization of the protein. Not only is immobilization necessary for the majority of practical applications such as localization of a protein on biosensor transducers, ${ }^{15}$ but immobilization of enzymes has also been demonstrated to improve enzyme stability by restricting unfolding ${ }^{16,17}$ or subunit dissociation ${ }^{18,19}$ and even to potentially enhance activity by kinetically trapping the enzyme in hyperactive conformations. $^{20,21}$ Nevertheless, effective immobilization of proteins and enzymes has proven challenging. Harsh immobilization chemistries and conditions can result in protein denaturation, $^{22}$ steric crowding or nonspecific protein orientation can hinder access to active sites, ${ }^{23}$ and encapsulation can restrict transport of substrates and products. $^{24,25}$ A variety of techniques have been developed to capture the benefits of immobilization while mitigating the drawbacks, such as using site-specific conjugation to control protein orientation $^{26}$ and using flexible linkers to relieve crowding. ${ }^{27}$ Additionally, various methods for nanopatterning of the protein utilizing lithography ${ }^{28-30}$ or self-assembled

Received: June 3, 2019

Revised: July 26, 2019 
templates allow for control over protein loading density and transport properties within biocatalysts. ${ }^{11,31,32}$

Direct self-assembly of enzymes in protein-polymer diblock copolymers offers a promising method for achieving control over nanostructure and protein orientation while maintaining stability and activity of the protein. Self-assembly of coil-coil diblock copolymers has been studied extensively, and a rich phase behavior encompassing a variety of nanostructured morphologies, such as micelles in dilute solution and lamellae, hexagonally packed cylinders, and gyroids in bulk, has been predicted theoretically and observed experimentally. ${ }^{33,34}$ These principles have been applied to globular protein-polymer diblocks, which have been increasingly investigated in part due to their ease of synthesis. ${ }^{35-37}$ Protein-polymer block copolymers have demonstrated the ability to form many ordered nanostructures, largely analogous to those observed in coil-coil diblocks, in dilute solution, concentrated solution, bulk solids, and thin films. ${ }^{38-42}$ Globular protein-polymer diblocks have also proven effective in heterogeneous catalysis and sensing applications. ${ }^{43-45}$

Although the phase behavior of coil-coil diblock copolymers is well understood, the monomers that comprise a globular protein are presented in a defined sequence and folded structure, resulting in topological and sequence-specific interactions between globular proteins. These spatially dependent structures and chemistries result in considerable anisotropy of ionic, hydrophobic, and hydrogen bonding interactions as well as complex sterics in the assembled domains from shape anisotropy of the globular structure. Simulations of polymer tethered nanoparticles have demonstrated shifting of phase boundaries resulting from different nanoparticle geometries, ${ }^{46}$ and polyhedra of different symmetries have been demonstrated to self-assemble into numerous crystalline, liquid crystalline, and disordered morphologies, ${ }^{47}$ suggesting that colloidal shape is an important factor in self-assembly. All of these effects make understanding the phase behavior of globular protein-polymer diblock copolymers a very complex problem.

Several studies have been performed on mCherry-polymer conjugate systems to elucidate the effects that govern selfassembly in protein-polymer block copolymers. Changes in polymer chemistry and chain topology have demonstrated significant shifts in phase transitions and observed nanostructures, ${ }^{48-50}$ and modifications to protein conjugation site have been shown to affect micellar stability as well as offer a handle for manipulation of protein orientation while keeping overall phase behavior relatively constant. ${ }^{51}$ However, modifications to the surface amino acid residues of the folded protein block have resulted in minimal changes to phase behavior, ${ }^{52}$ while large modifications of the overall charge of superfolder GFP (sfGFP) have demonstrated significantly improved ordering for neutrally charged variants and suppressed ordering for supercharged variants. This demonstrates that overall charge is one method of controlling ordering. ${ }^{53}$ These findings also suggest that coarse-grained properties such as protein size, shape, and other colloidal properties may prove to be better predictors of self-assembly than the specific amino acid sequence of the protein.

Herein, the self-assembly behavior of 15 distinct protein- $b$ poly( $N$-isopropylacrylamide) (PNIPAM) conjugates in concentrated solution is investigated using small-angle $\mathrm{X}$-ray scattering (SAXS). Within this set of 15 bioconjugates, seven have been newly synthesized for this study, with the remainder taken from the existing literature. The full structural data set is analyzed for correlations between various physical and chemical properties of the proteins with various metrics of ordering, particularly focusing on quality of ordering within the observed phases, boundaries of the phase transitions, and the identity of each observed phase. It is found that a model incorporating only protein molecular weight and percent of residues contained within $\beta$ sheets can account for the majority of the variation in ordering quality.

\section{METHODS}

Polymer Synthesis. PNIPAM of various molecular weights was synthesized using reversible addition-fragmentation chain-transfer (RAFT) polymerization using a maleimide-functionalized chaintransfer agent, as previously reported. ${ }^{42}$ The molar masses and dispersities of all PNIPAM samples are included in Table 1, and gel permeation chromatography (GPC) traces for each of the newly synthesized polymers are included in Figure S1.

Table 1. Characterization of Proteins and Polymers Used

\begin{tabular}{|c|c|c|c|c|}
\hline Protein & $\begin{array}{l}\text { Protein MW } \\
\quad(\mathrm{kDa})\end{array}$ & $\begin{array}{l}\text { PNIPAM } M_{\mathrm{n}} \\
(\mathrm{kDa})\end{array}$ & PNIPAM $Đ$ & $\begin{array}{l}\text { PNIPAM Weight } \\
\text { Fraction }\end{array}$ \\
\hline rcSso7d & 9.4 & 9.8 & 1.09 & 0.51 \\
\hline $\mathrm{HMb}$ & 19.7 & 18.9 & 1.10 & 0.49 \\
\hline mCherry & 28.1 & 29.0 & 1.11 & 0.51 \\
\hline EGFP & 29.5 & 26.3 & 1.10 & 0.47 \\
\hline HCAII & 29.4 & 29.0 & 1.11 & 0.50 \\
\hline HTPI & 27.9 & 29.0 & 1.11 & 0.51 \\
\hline DFPase & 36.1 & 40.9 & 1.09 & 0.53 \\
\hline PhoA & 48.7 & 49.7 & 1.07 & 0.51 \\
\hline P450 & 54.7 & 55.4 & 1.04 & 0.50 \\
\hline BSA & 66.7 & 66.6 & 1.07 & 0.50 \\
\hline IgG & 149.0 & 68.5 & 1.04 & 0.31 \\
\hline
\end{tabular}

Protein Biosynthesis and Purification. The genes encoding native diisopropyl fluorophosphatase (DFPase) ( $^{54}$ and human carbonic anhydrase II (HCAII $)^{55}$ contained in vector $\mathrm{pET} 15 \mathrm{~b}$ were purchased from GenScript, the plasmid containing the sequence for human triosephosphate isomerase (HTPI) ${ }^{56}$ in vector $\mathrm{pET} 20 \mathrm{~b}$ was a gift from Dr. Markus Ralser (Addgene plasmid \# 50723), and the gene for Alkaline Phosphatase (PhoA) in the pTrc99a plasmid was obtained as a gift from Dr. Jeff Glasgow. To introduce conjugation sites into these sequences, site-directed mutagenesis was performed using a QuikChange II XL kit (product \#200521, Agilent) to produce variants with an $\mathrm{N}$-terminal cysteine for DFPase (DFPaseN), a Cterminal cysteine for DFPase (DFPaseC), an S43C mutation for HCAII, an S4C mutation for HTPI, and a T93C mutation for PhoA. Each plasmid was then transformed into the Escherichia coli expression cell line Tuner(DE3) (product \#70623, Novagen). The sequences for each of these genes and the expressed proteins are provided in the Supporting Information. Each protein was biosynthetically expressed in $1 \mathrm{~L}$ media in $2.8 \mathrm{~L}$ Fernbach flasks within a shaking incubator. The expression conditions for each protein are summarized in Table 2, along with the typical yield for each protein after purification.

Cell pellets for expressed proteins DFPase, HCAII, and HTPI were harvested by centrifugation at $4000 \mathrm{~g}$, resuspended in lysis buffer $(50$ $\mathrm{mM} \mathrm{NaH} \mathrm{PO}_{4}, 300 \mathrm{mM} \mathrm{NaCl}, 10 \mathrm{mM}$ imidazole, $10 \mathrm{mM} \beta$ mercaptoethanol (BME), adjusted to $\mathrm{pH} 8.0$ with $\mathrm{NaOH}$ ), and incubated with $1 \mathrm{mg} / \mathrm{mL}$ lysozyme at $4{ }^{\circ} \mathrm{C}$ for $30 \mathrm{~min}$ prior to sonication. The cell lysate was then clarified by centrifugation, and the proteins were bound to Ni-NTA resin overnight. The bound resin was washed with 10 column volumes of wash buffer $\left(50 \mathrm{mM} \mathrm{NaH} \mathrm{PO}_{4}\right.$, $300 \mathrm{mM} \mathrm{NaCl}, 20 \mathrm{mM}$ imidazole, $10 \mathrm{mM}$ BME, adjusted to $\mathrm{pH} 8.0$ with $\mathrm{NaOH}$ ) and then eluted using 5 column volumes of elution buffer $(300 \mathrm{mM} \mathrm{NaCl}, 250 \mathrm{mM}$ imidazole, $10 \mathrm{mM}$ BME, adjusted to pH 8.0 with $\mathrm{NaOH}$ ). Following Ni-NTA purification, the proteins were dialyzed against $20 \mathrm{mM}$ Tris- $\mathrm{Cl}$ buffer at $\mathrm{pH}$ 8.0. Protein purity 
Table 2. Expression Conditions for Proteins

\begin{tabular}{|c|c|c|c|c|c|}
\hline Protein & Cell Line & Media & Induction conditions & Growth conditions & $\begin{array}{c}\text { Approximate yield } \\
(\mathrm{mg} \text { protein } / \mathrm{L} \text { culture })\end{array}$ \\
\hline HTPI & Tuner(DE3) & LB + Ampicillin & $0.5 \mathrm{mM}$ IPTG added at $\mathrm{OD}_{600}=0.5$ & $37^{\circ} \mathrm{C}$ for $6 \mathrm{~h}$ after induction & 30 \\
\hline HCAII & Tuner(DE3) & LB + Ampicillin & $1.0 \mathrm{mM}$ IPTG added at $\mathrm{OD}_{600}=1.0$ & $37^{\circ} \mathrm{C}$ for $6 \mathrm{~h}$ after induction & 50 \\
\hline DFPase & Tuner(DE3) & LB + Ampicillin & No induction & $30{ }^{\circ} \mathrm{C}$ for $24 \mathrm{~h}$ & 30 \\
\hline P450 & Tuner(DE3) & LG + Ampicillin & $1.0 \mathrm{mM}$ IPTG added at $\mathrm{OD}_{600}=1.0$ & $\begin{array}{c}25^{\circ} \mathrm{C} \text { for } 12 \mathrm{~h} \text { after induction; } \\
\text { low shake rate }(150 \mathrm{rpm})\end{array}$ & 20 \\
\hline PhoA & Tuner(DE3) & 2xYT + Ampicillin & $\begin{array}{l}1.0 \mathrm{mM} \text { IPTG, } 1 \mathrm{mM} \mathrm{MgSO} \\
\mathrm{ZnSO}_{4} \text { added at } \mathrm{OD}_{600}=0.4\end{array}$ & $37^{\circ} \mathrm{C}$ for $12 \mathrm{~h}$ after induction & 50 \\
\hline
\end{tabular}

was assessed using sodium dodecyl sulfate polyacrylamide gel electrophoresis (SDS-PAGE) (Figures S2-4).

Cell pellets for PhoA were harvested by centrifugation at $3500 \mathrm{~g}$ and resuspended in $50 \mathrm{mM}$ Tris $-\mathrm{Cl}$ buffer at $\mathrm{pH}$ 8. Pelleting and resuspension were then repeated to remove impurities. The periplasm was isolated by adding solid sucrose $(0.5 \mathrm{M})$, ethylenediaminetetraacetic acid (EDTA, $2.5 \mathrm{mM}$ ), and lysozyme $\left(0.6 \mathrm{mg} \mathrm{mL}^{-1}\right)$ to the cells and incubating at $37{ }^{\circ} \mathrm{C}$ for $30 \mathrm{~min}$. The sphaeroplasts were removed by centrifuging at $10,000 \mathrm{~g}$ for $20 \mathrm{~min}$. The resulting supernatant was the periplasmic fraction. The supernatant was

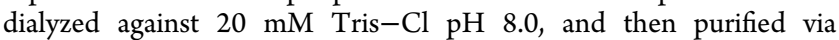
anion exchange fast protein liquid chromatography (FPLC) using a 5 mL HiTrap Q HP column (product \#17115401, GE Healthcare) on an AKTA Pure FPLC (GE Healthcare) with $20 \mathrm{mM}$ Tris-Cl pH 8.0 containing $5 \mathrm{mM}$ BME as the mobile phase. The protein was eluted from the column using a linear $0-0.5 \mathrm{M} \mathrm{NaCl}$ gradient. The purified fractions, determined by SDS-PAGE, were combined and dialyzed against $20 \mathrm{mM}$ Tris- $\mathrm{Cl} \mathrm{pH} 8.0$ containing $1 \mathrm{mM} \mathrm{MgSO}_{4}$ and $0.1 \mathrm{mM}$ $\mathrm{ZnSO}_{4}$.

Bovine serum albumin (BSA) was purchased from Millipore-Sigma (product A2153) and purified by anion exchange FPLC using $5 \mathrm{~mL}$ HiTrap Q HP anion exchange columns (GE Healthcare) on an AKTA Pure FPLC (GE Healthcare) with $20 \mathrm{mM}$ Tris-Cl pH 8.0 as the mobile phase. The protein was eluted from the column using a linear $0-0.3 \mathrm{M} \mathrm{NaCl}$ gradient.

Protein Bioconjugation to PNIPAM. Proteins were coupled to PNIPAM using thiol-maleimide coupling chemistry. The protein solutions were diluted to either 1 or $0.5 \mathrm{mg} / \mathrm{mL}$ in $20 \mathrm{mM}$ Tris $-\mathrm{HCl}$ buffer. For most bioconjugations, $10 \mathrm{~mol}$ equiv of tris(2-caroxyethyl)phosphine (TCEP) was added, and the solutions were stirred for 30 min at $4{ }^{\circ} \mathrm{C}$ to reduce thiol groups. PNIPAM was added in stoichiometric ratios between 2:1 and 10:1 to the protein solution, and the resulting mixtures were stirred overnight at $4{ }^{\circ} \mathrm{C}$. The reaction conditions for each of the different conjugates are summarized in Table 3. The DFPase, PhoA, and BSA conjugates

\section{Table 3. Bioconjugation Conditions for Each Protein}

\begin{tabular}{lccc} 
Protein & $\begin{array}{c}\text { Protein } \\
\text { Concentration } \\
(\mathrm{mg} / \mathrm{mL})\end{array}$ & $\begin{array}{c}\text { TCEP Concentration } \\
\text { (protein molar } \\
\text { equivalents) }\end{array}$ & $\begin{array}{c}\text { PNIPAM } \\
\text { Concentration (protein } \\
\text { molar equivalents) }\end{array}$ \\
HTPI & 1.0 & 10 & 5 \\
HCAII & 1.0 & 10 & 5 \\
DFPase & 1.0 & 10 & 3 \\
PhoA & 1.0 & 10 & 10 \\
P450 & 1.0 & 10 & 10 \\
BSA & 0.5 & 5 & 2 \\
\hline
\end{tabular}

were then purified using $5 \mathrm{~mL}$ HiTrap Q HP anion exchange columns (GE Healthcare) on an AKTA Pure FPLC (GE Healthcare) with 20 $\mathrm{mM}$ Tris $-\mathrm{Cl} \mathrm{pH} 8.0$ as the mobile phase. The protein was eluted from the column using a linear $0-0.3 \mathrm{M} \mathrm{NaCl}$ gradient. The purified fractions, determined by SDS-PAGE (Figures S5-7), were combined. HCAII and HTPI conjugates were purified by precipitation in $1.0 \mathrm{M}$ ammonium sulfate three times and then bound to Ni-NTA resin for $24 \mathrm{~h}$. The resin was then washed with 12 column volumes of $4^{\circ} \mathrm{C}$ deionized water and eluted using 5 column volumes of elution buffer
( $300 \mathrm{mM} \mathrm{NaCl}, 250 \mathrm{mM}$ imidazole, adjusted to $\mathrm{pH} 8.0$ with $\mathrm{NaOH}$ ). Bioconjugate purity was confirmed using SDS-PAGE (Figures S8 and S9). Following purification, the conjugate solutions were concentrated to approximately $100-200 \mathrm{mg} / \mathrm{mL}$ using Millipore Ultra- 15 centrifugal filters, and $20 \mu \mathrm{L}$ aliquots were deposited as droplets onto poly(tetrafluoroethylene) sheets. The droplets were then dried to solid pellets by ramping the pressure within the chamber down at a rate of $100 \mathrm{Torr} / \mathrm{h}$, and then holding at the lowest achievable pressure ( $\sim 13$ Torr) for an additional $12 \mathrm{~h}$. The resulting solid pellets were stored at $4{ }^{\circ} \mathrm{C}$ until use.

Small-Angle X-ray Scattering (SAXS). Concentrated solutionstate samples for SAXS were prepared by hydrating the pellets to the desired concentration and then sealing the concentrated bioconjugate solutions into the center of $1 \mathrm{~mm}$ thick aluminum washers using Kapton tape. SAXS patterns were obtained at the Advanced Photon Source (APS) at Argonne National Lab on beamline 12-ID-C for DFPase and BSA, the Stanford Synchrotron Radiation Lightsource (SSRL) on beamline 1-5 for HCAII, PhoA, and P450, and the Advanced Light Source (ALS) at Lawrence Berkeley National Lab on beamline 7.3.3 for HTPI. Samples were equilibrated for $10 \mathrm{~min}$ before measurement at each temperature, and the collected data were corrected for empty cell scattering.

Circular Dichroism (CD) Spectroscopy. CD spectroscopy was performed to confirm proper folding of expressed proteins at all stages of sample preparation (Figure S10). Measurements were completed using a JASCO Model J-1500 CD spectrometer to measure far UV CD spectroscopy between 195 and $250 \mathrm{~nm}$ in a $0.1 \mathrm{~cm}$ path length quartz cuvette. All proteins were measured in $20 \mathrm{mM}$ Tris- $\mathrm{Cl}$ buffer at $\mathrm{pH}$ 8.0, except for PhoA, for which the buffer also contained $1 \mathrm{mM}$ $\mathrm{MgSO}_{4}$ and $0.1 \mathrm{mM} \mathrm{ZnSO}$.

Protein Physical and Structural Parameter Determination. The size, shape, and structure of proteins were quantified with parameters estimated using the PDB files for each studied protein: Sso7d (PDB: 1SSO), ${ }^{57} \mathrm{HMb}$ (PDB: 1A6G), ${ }^{58}$ mCherry (PDB: 2H5Q), ${ }^{59}$ EGFP (PDB: 2Y0G), ${ }^{60}$ HCAII (PDB: 5JDV), ${ }^{61}$ HTPI (PDB: 7TIM), ${ }^{62}$ DFPase (PDB: 3O4P), ${ }^{63}$ PhoA (PDB: 5C66), ${ }^{64}$ P450 (PDB: 1WOE), ${ }^{65}$ BSA (PDB: 3 V03), ${ }^{66}$ and IgG (PDB: IIGT) ${ }^{67}$ Protein volume, surface area, sphericity, and effective radius (the radius of a sphere with the same surface area-to-volume ratio as the protein) were calculated on the $3 \mathrm{~V}$ server using high grid resolution. ${ }^{68}$ The number and percentage of residues contained within $\alpha$ helices, $\beta$ sheets, and coil regions of each protein were determined using the VADAR server. ${ }^{69}$ All calculated parameter values are listed in Table S1.

Development of Predictive Model for Bioconjugate Ordering Quality. Regression analysis was performed using JMP software. All variables listed in Table $S 1$ were used in the preliminary regression except for protein volume due to the high correlation between volume and molecular weight. Volume was removed from the model instead of molecular weight to additionally remove the interdependence between volume, surface area, and sphericity. A complete methodology for model development, including training, testing, and validation, is provided in the Supporting Information.

\section{RESULTS AND DISCUSSION}

Self-Assembly Behavior of New Bioconjugates. While in traditional coil-coil diblock copolymers it is widely 
Scheme 1. General Synthetic Scheme for Conjugation of a Cysteine-Modified Protein to Maleimide-Functionalized PNIPAM To Form Protein-PNIPAM Bioconjugates

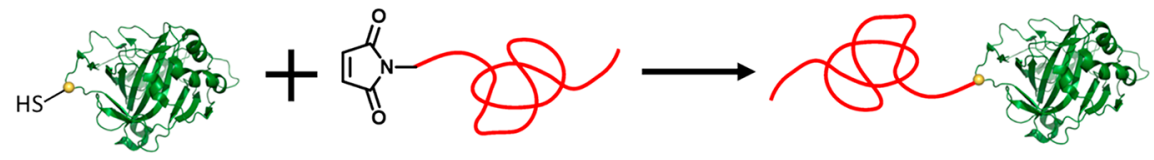

accepted that a single universal phase diagram is representative of the behavior of the molecules regardless of the specific chemistry of each block, it is unclear whether the great diversity of proteins can be understood in terms of a similarly coarse-grained representation. To understand how protein variation impacts self-assembly, a relatively large sampling of structurally different protein-polymer bioconjugates has been prepared and compared, including eight bioconjugates consisting of five proteins from previously published studies and a set of seven new conjugates from six new proteins. All bioconjugates are protein-PNIPAM block copolymers. PNIPAM was selected as the polymer block, as conjugates incorporating this polymer have been shown to form ordered phases under the widest range of concentrations. ${ }^{48,49}$ Each of the six new conjugates was synthesized from proteins of various structures, properties, and functions: HCAII, HTPI, DFPase, PhoA, Cytochrome P450, and BSA. To form bioconjugates, these proteins were expressed biosynthetically, or, in the case of BSA, purchased from a commercial source and purified. These proteins were then used to synthesize bioconjugates via site-specific bioconjugation chemistry using thiol-maleimide coupling (Scheme 1). In addition to these six conjugates, structural data of conjugates of reduced charged Sso7d (rcSso7d), ${ }^{45}$ human heart myoglobin ( $\left.\mathrm{HMb}\right),{ }^{44}$ human immunoglobulin G (IgG), ${ }^{43}$ mCherry, ${ }^{51}$ and $\mathrm{EGFP}^{52}$ from other studies were compared to identify trends in how the properties of each protein affects the quality of ordering and general self-assembly behavior of protein-polymer bioconjugates. For the six bioconjugates in this study as well as the referenced bioconjugates, the weight fraction of protein and polymer was kept roughly symmetric except in the case of IgG, where the mass of the protein was too large to form a symmetric conjugate. The cartoon folded structures with marked conjugation sites for each of these 11 proteins is shown in Figure 1 approximately to scale, and characterization details of each protein and polymer used in this study are summarized in Table 1.

SAXS was used to identify order-disorder transitions (ODTs) and order-order transitions (OOTs) for each bioconjugate sample as a function of both temperature and concentration. Phase diagrams for each of the six new bioconjugates are shown in Figure 2. In each case, a disordered phase is observed at low concentrations. This phase is characterized either by the absence of any peak or by a single broad peak resulting from the correlation hole effect for block copolymers. ${ }^{70}$ Characteristic SAXS traces for this phase as well as each observed phase for each bioconjugate can be found in Figure 3. For each conjugate at concentrations of $30 \mathrm{wt} \%$ and below, heating the samples to $35{ }^{\circ} \mathrm{C}$ results in a transition to a disordered micellar phase, as evidenced by a sharpening of the primary peak accompanied by at least one broad, higher order peak. This phase separation is consistent with observations in mCherry, EGFP, HMb, and rcSso7d systems ${ }^{44,45,52}$ and is attributed to water becoming a poor solvent for PNIPAM above its lower critical solution temperature (LCST). As

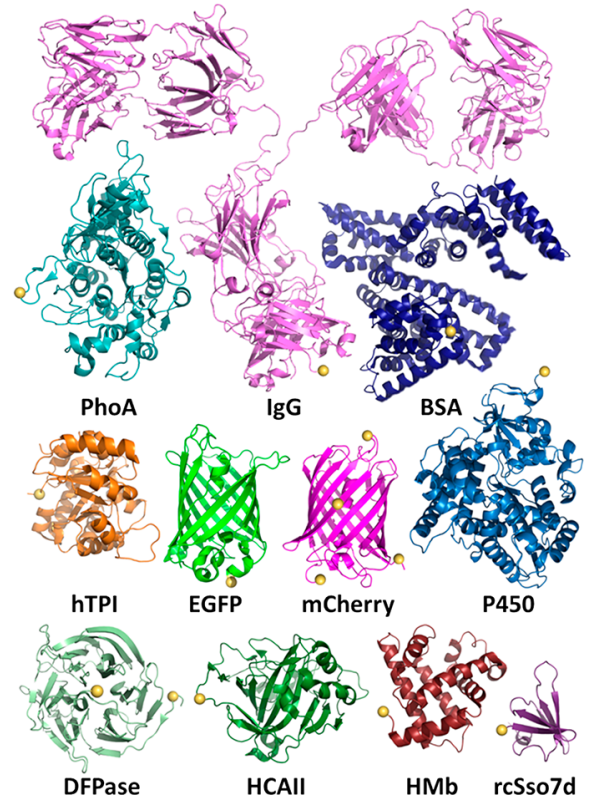

Figure 1. Panel of 11 proteins. Images are rendered approximately toscale. All studied conjugation sites are marked with yellow spheres.

concentration is increased, a concentration ODT $\left(C_{\mathrm{ODT}}\right)$ is observed to the lamellar phase for each protein with the exceptions of rcSso7d and $\mathrm{P} 450$, which remain disordered. The lamellar phase is characterized by scattering peaks at $\mathrm{q}^{*}$ and $2 \mathrm{q}^{*}$. This transition occurs between 40 and $50 \mathrm{wt} \%$ for $\mathrm{HMb}$, between 40 and 45 wt $\%$ for DFPaseC, and between 45 and 50 wt $\%$ for BSA, HCAII, and HTPI, and DFPaseN. These $C_{\text {ODT }}$ values are considerably higher than for EGFP and mCherry, which have $C_{\mathrm{ODT}}$ values as low as 30 wt $\%{ }^{40,51,52}$ Additionally, 3 of the proteins exhibit ODT temperatures ( $T_{\mathrm{ODT}}$ values) at concentrations of 40 and 45 wt \%: HTPI transitions from the disordered phase to a hexagonal phase, and both DFPaseN and BSA transition from disordered to lamellar phases. These transitions are likely due to desolvation of the polymer resulting in phase separation as the water partitions to the protein domains. However, this type of thermotropic transition has not previously been observed in other protein-polymer block copolymer systems.

Moving the conjugation site of DFPase between the $\mathrm{N}$ terminus and C-terminus shows very little effect on the phase behavior. Micellar stability is observed to be very similar, but a very slight change in $C_{\mathrm{ODT}}$ is observed, with DFPaseN transitioning from disordered to lamellar between 45 and 47 wt $\%$ at low temperatures, and DFPaseC transitioning between 40 and 45 wt \%. DFPaseC also exhibits $T_{\mathrm{ODT}}$ values from disordered to micellar at 30 and $25{ }^{\circ} \mathrm{C}$ for 40 and $45 \mathrm{wt} \%$ samples, respectively, while this behavior is not observed for DFPaseN. Although there are shifts in phase boundaries between these two conjugates, the differences are small. Previous studies on conjugation-site modified mCherryPNIPAM conjugates ${ }^{51}$ have shown similarly minor effects on 

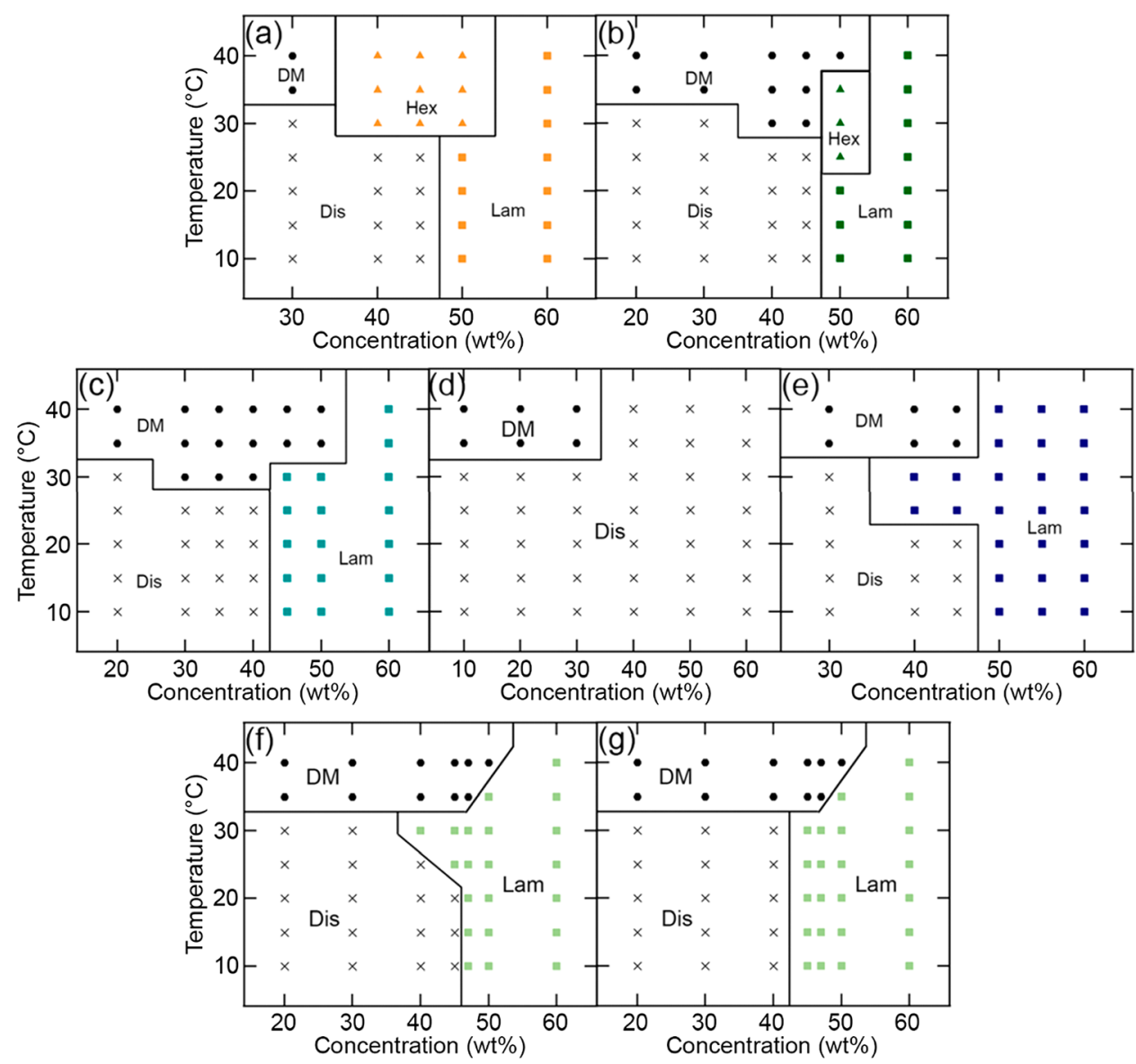

Figure 2. Concentration vs temperature phase diagrams for (a) HTPI, (b) HCAII, (c) PhoA, (d) P450, (e) BSA, (f) DFPaseN, (g) DFPaseC. Phases are labeled as disordered (Dis), disordered micellar (DM), lamellar (lam), and hexagonal (hex).

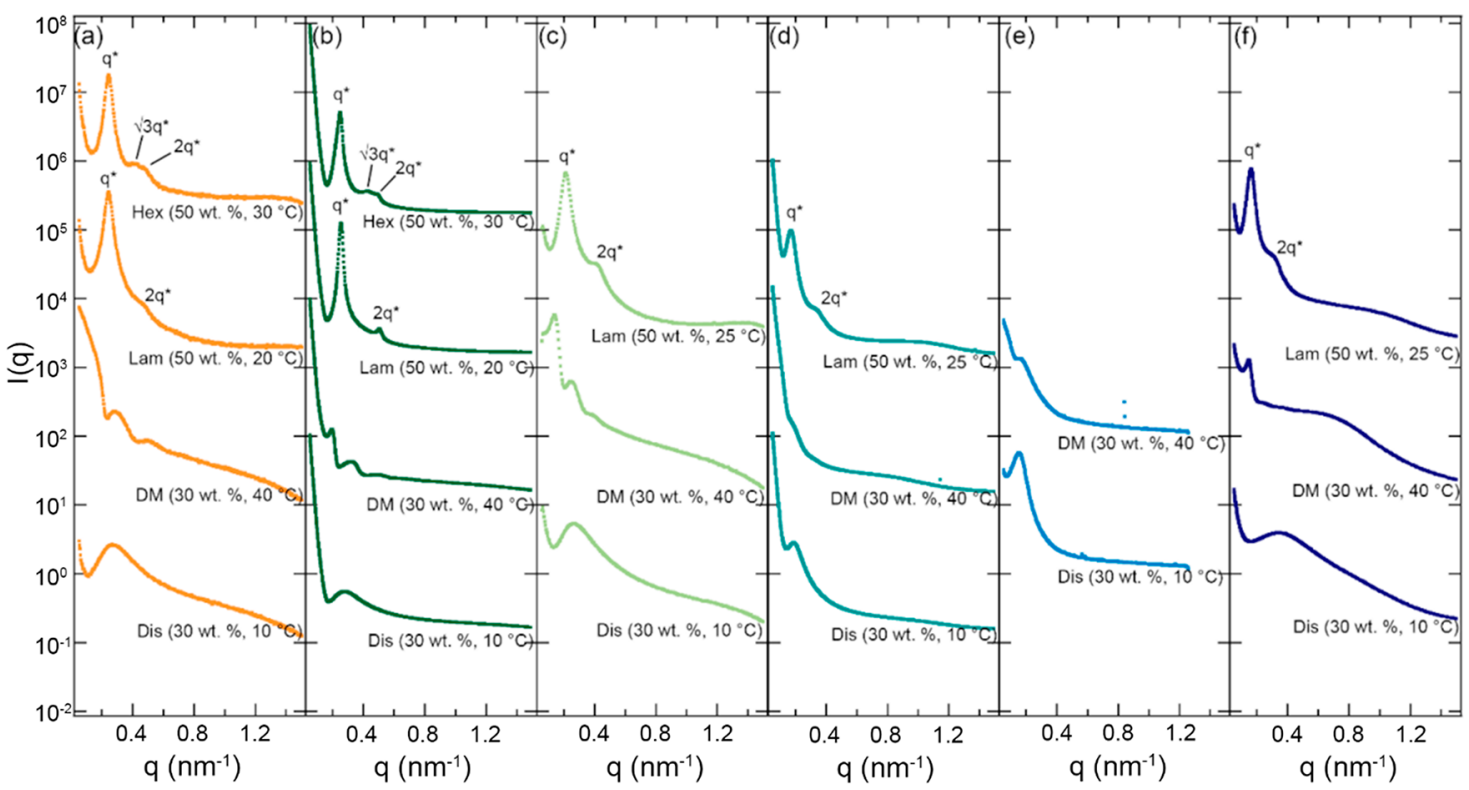

Figure 3. Representative SAXS patterns for each phase observed in (a) HTPI, (b) HCAII, (c) DFPase, (d) PhoA, (e) P450, and (f) BSA bioconjugates.

phase boundaries, suggesting that the phase transitions within protein-polymer bioconjugates are generally insensitive to changes in conjugation site.

Ordering Quality Trends. Although all of the symmetric bioconjugates that form self-assembled phases display regions of lamellar ordering, the lamellar phases of the previously studied and newly characterized proteins exhibit widely varying degrees of ordering. This is demonstrated by a comparison of the sharpness of the primary scattering peaks, which indicates the ability of the conjugates to assemble into highly correlated 
lamellar nanostructures. Peak sharpness was quantified using the inverse full width at half-maximum $\left(\mathrm{fwhm}^{-1}\right)$ of the peak and was calculated by fitting a Lorentzian function to the primary scattering peak:

$$
I(q)=I_{0}\left[\frac{\gamma^{2}}{\left(q-q_{0}\right)^{2}+\gamma^{2}}\right]
$$

where $I_{0}$ is the peak height, $q_{0}$ is the peak position, and $2 \gamma$ is the fwhm. Though greater values of $\mathrm{fwhm}^{-1}$ do correspond to higher ordering quality, the relationship between these two variables is nonlinear. As such, quantitative comparisons between fwhm ${ }^{-1}$ values do not necessarily reflect commensurate comparisons in ordering quality. Rather, fwhm ${ }^{-1}$ provides a useful metric by which the relative ordering quality of conjugates can be compared. In a preliminary attempt to understand trends in this metric of ordering, the fwhm ${ }^{-1}$ was plotted against several coarse-grained biophysical properties of the proteins: protein volume, effective radius, sphericity, surface area, molar mass, and secondary structure content (Figures 4, S11-17).

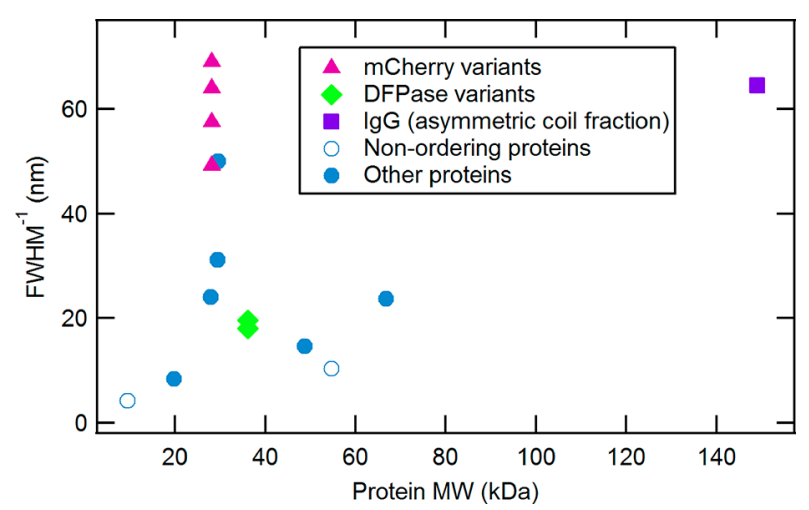

Figure 4. Quality of ordering, quantified as $\mathrm{fwhm}^{-1}$, as a function of protein molecular weight illustrating a trend of increasing order with molecular weight with a small range of greatly improved ordering. Data are presented for $50 \mathrm{wt} \%$ bioconjugate solutions at $25{ }^{\circ} \mathrm{C}$.

Protein molar mass was found to display the most prominent trend with ordering quality (Figure 4). Based on the well-known behavior of other block copolymer systems, it is natural to expect that the quality of ordering improves with the size (molar mass) of the bioconjugate. This expectation originates from block copolymer self-assembly theories, ${ }^{71,72}$ which demonstrate that the segregation strength of the blocks scales as $\chi N$ : the product of the Flory-Huggins interaction parameter and the copolymer degree of polymerization. While the theory is not applicable to protein-polymer conjugates, this trend is nonetheless observed in these protein-polymer diblocks up to a protein molar mass of approximately $30 \mathrm{kDa}$. However, beyond this point, the quality of ordering begins to decrease. While the smaller diblocks of rcSso7d and $\mathrm{HMb}$ may be too weakly segregated to order well, ordering in the larger diblocks of BSA, P450, and PhoA is likely hindered by low chain mobility from chain entanglement. Indeed, the molar masses of the PNIPAM samples conjugated to these proteins (66.6, 55.4, and $49.7 \mathrm{kDa}$, respectively) all fall within the expected $37.5-75 \mathrm{kDa}$ range for the entanglement molar mass in a $50 \mathrm{wt} \%$ solution (calculation of this range is provided in the Supporting Information). Chain entanglement is expected to have a significant effect on the self-assembly of proteinPNIPAM conjugates since these conjugates cannot be thermally annealed to reach an equilibrium state without denaturing the protein block. As such, entanglements likely greatly or completely restrict diffusion of large, rigid proteins, kinetically trapping the conjugates in a nonequilibrium state, which has been demonstrated in systems of analogously rigid nanoparticles in entangled polymer networks and melts. ${ }^{73}$ This results in a small window of molecular weights that allow for both high segregation strength of the blocks as well as sufficient chain mobility to self-assemble into well-ordered phases.

Temperature is also found to significantly affect ordering quality in the studied bioconjugates. For the majority of the bioconjugates, the sharpness of the primary peak increases with temperature, indicating improved ordering within the observed lamellar phase (Figure 5). This effect results from increased

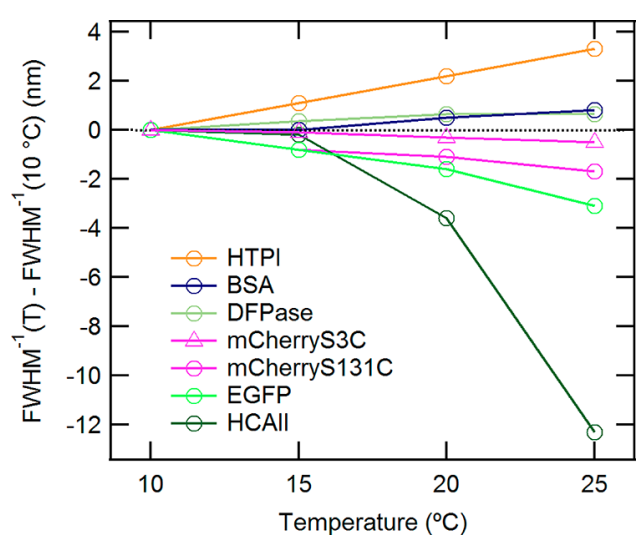

Figure 5. fwhm ${ }^{-1}$ of the primary peaks for lamellar phases observed in $50 \mathrm{wt} \%$ bioconjugates. This concentration was chosen as it is the condition where every bioconjugate studied here except for $\mathrm{rcSso} 7$ displays a lamellar phase.

segregation strength between the domains as the temperature approaches the transition temperature of PNIPAM (between 30 and $35{ }^{\circ} \mathrm{C}$ for most of the conjugates), causing the solvent to become more selective for the protein block. The small magnitude of these differences in ordering quality is consistent with observations that solvent quality of water for PNIPAM only changes slightly between 10 and $25{ }^{\circ} \mathrm{C} .{ }^{74}$ Oddly, the bestordered bioconjugates - mCherry, EGFP, and HCAII- exhibit the opposite trend, where quality of ordering decreases with increasing temperature. This behavior may suggest that the entropic penalty for forming well-ordered domains exhibited by these three bioconjugates is sufficiently high such that it dominates other temperature-dependent factors. Regardless of the physical origin, this difference strongly implies that for mCherry, EGFP, and HCAII, there is a difference in the nature of the forces governing their self-assembly that leads to greater ordering quality.

Although protein molecular weight displays a clear trend with quality of ordering measured by peak sharpness, when compared to $C_{\mathrm{ODT}}$, another metric of segregation strength, no such trend is observed (Figures 6, S18-21). $C_{\mathrm{ODT}}$ values for each studied protein occur between 40 and $50 \mathrm{wt} \%$, with the exception of the $\beta$-barrel proteins mCherry and EGFP. It is worth noting that modifications to the conjugation sites of mCherry and DFPase have been shown to shift the $C_{\mathrm{ODT}}$ without significant change to the overall quality of ordering of 


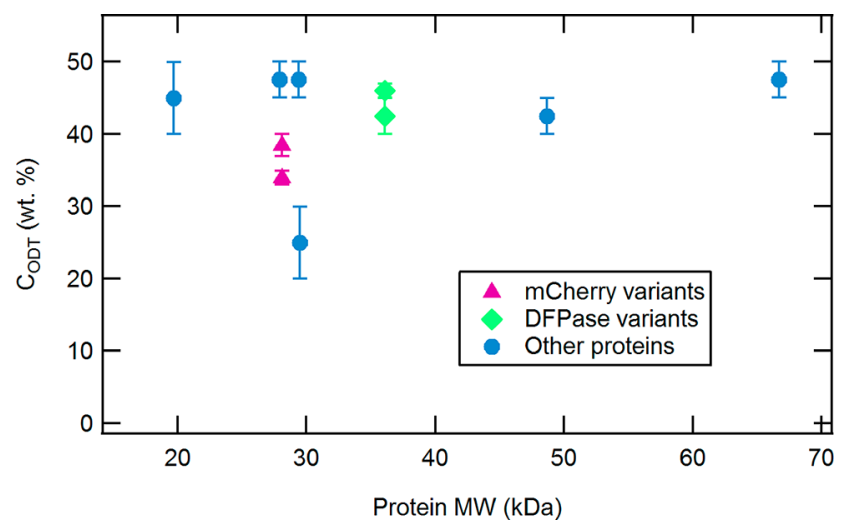

Figure 6. $C_{\mathrm{ODT}}$ as a function of protein molecular weight. Error bars indicate the concentration resolution of the SAXS measurements used to determine phase transitions. Data are presented for $50 \mathrm{wt} \%$ bioconjugate solutions at $25{ }^{\circ} \mathrm{C}$.

the structured phases above the $C_{\mathrm{ODT}} \cdot{ }^{51}$ Similarly, studies altering the charge of superfolder GFP have demonstrated that quality of ordering can be suppressed without shifting $C_{\mathrm{ODT}} \cdot{ }^{53}$ These findings imply that quality of ordering within the structured nanophases and the transition boundaries for the observed phases can be controlled independently.

The type of phase formed by the block copolymers at a constant coil fraction also depends on molar mass. This is possible even in the coarse-grained colloid-polymer framework because changing the molar mass can also alter the relative aspect ratio of the molecule, an effect that has been extensively observed in rod-coil systems. ${ }^{75}$ While all ordered bioconjugates exhibit a lamellar phase, a hexagonally packed phase, characterized by scattering peaks at $\mathrm{q}^{*}, \sqrt{3} \mathrm{q}^{*}$, and $2 \mathrm{q}^{*}$, is observed in only 4 of the proteins: mCherry, EGFP, HCAII, and HTPI. This OOT only occurs above $25^{\circ} \mathrm{C}$, as the higher temperatures lead to water becoming a poor solvent for PNIPAM, resulting in deswelling of the polymer domains. The corresponding reduced coil volume fraction results in a collapse of the polymer domain into hexagonally packed cylinders. Interestingly, all 4 proteins that exhibit this phase are all bounded within the same molecular weight range of 20-36 $\mathrm{kDa}$. While the transition boundaries for the hexagonal phase differ, the observation of the hexagonal phase is ubiquitous for all symmetric protein-polymer bioconjugates in this size range studied at these conditions, with the existence of this phase being robust to conjugation site, ${ }^{51}$ protein charge, ${ }^{53}$ and polymer chemistry. ${ }^{48,49}$ However, no other conjugates exhibit this phase, not even well-ordered conjugates such as BSA or IgG. ${ }^{43}$ Instead, these conjugates tend to remain lamellar up to the highest measured temperature of $40{ }^{\circ} \mathrm{C}$. Even for IgG bioconjugates with small PNIPAM coil fraction, a condition demonstrated to promote the hexagonal phase in mCherry and EGFP systems, ${ }^{52,76}$ the hexagonal phase is absent. The observation of a small window of hexagonally packed ordering seemingly independent of ordering quality suggests that for the bioconjugate to exhibit a hexagonal phase, the size of the protein is critical for accommodating the additional interfacial curvature of this phase. As such, there may only be a narrow region within the compositional space of solution phase protein-polymer bioconjugates where the hexagonal phase is accessible.

Predicting Bioconjugate Ordering Quality. A predictive model for the expected bioconjugate ordering quality in terms of $\mathrm{fwhm}^{-1}$ was generated using only the protein biophysical properties considered in this study. By reducing the full set of properties to a subset of those most strongly correlated with $\mathrm{fwhm}^{-1}$ using regression analysis, it was determined that an accurate model could be constructed using only four terms with six total coefficients: a constant, a term linear in molecular weight, a Lorentzian fit to the peak in the molecular weight data, and a term linear in $\%$ residues in $\beta$ sheets. The corresponding model is presented below:

$$
\begin{aligned}
\text { Predicted fwhm } & -1= \\
& +42\left[\frac{0.97^{2}}{(\mathrm{MW}-28.4)^{2}+0.97^{2}}\right] \\
& +0.3 \beta
\end{aligned}
$$

where MW is molecular weight in $\mathrm{kDa}$ and $\beta$ is the percentage of residues in $\beta$ sheets. Error bounds on the coefficients and $p$ values for each parameter in the model are listed in Table 4.

Table 4. Best-Fit Parameter Values and Statistical Significance

\begin{tabular}{lcl} 
& Coefficient & \\
\multicolumn{1}{c}{ Term } & $p$-Value \\
Intercept & $-9 \pm 6$ & 0.1816 \\
MW (linear) & $0.38 \pm 0.08$ & $0.0009^{*}$ \\
MW (Lorentzian) peak height & $42 \pm 8$ & $0.0001^{*}$ \\
MW (Lorentzian) peak position & $28.4 \pm 3.7$ & $0.0001^{*}$ \\
MW (Lorentzian) peak growth rate & $0.97 \pm 0.60$ & 0.1055 \\
\% Beta sheets & $0.3 \pm 0.1$ & $0.0001^{*}$
\end{tabular}

${ }^{a}$ Ranges represent the $95 \%$ confidence interval for parameter estimates. ${ }^{b}$ Values calculated using F-test of overall significance. Asterisk indicates statistical significance at the $\alpha=0.05$ level.

The ordering quality model overall shows good agreement with the experimentally measured fwhm ${ }^{-1}$ values (Figure 7).

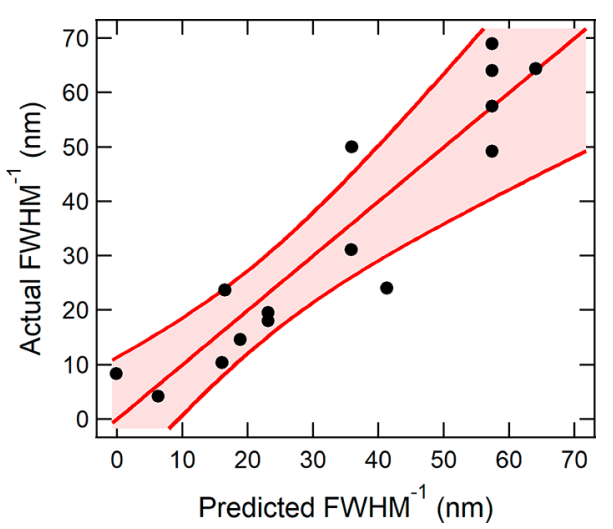

Figure 7. Comparison of actual and predicted $\mathrm{fwhm}^{-1}$ values for 50 wt \% bioconjugate solutions at $25{ }^{\circ} \mathrm{C}$. Shaded region represents $95 \%$ confidence region.

The model requires very little information about a protein, only including variables that provide coarse-grained descriptions of protein size (molecular weight) and structure (\% residues in $\beta$ sheets). Despite its simplicity and small sample size, the model is surprisingly accurate, accounting for over $86 \%$ of the observed variation in $\mathrm{fwhm}^{-1}$ values and is estimated to explain over $75 \%$ of the variation in $\mathrm{fwhm}^{-1}$ when predicting conjugate ordering (Table 5). This accuracy is 
Table 5. Regression Statistics

$\begin{array}{lc}\text { Regression Statistic } & \text { Value } \\ \text { R-squared } & 0.862 \\ \text { Adjusted R-squared } & 0.825 \\ \text { Predicted R-squared } & 0.758\end{array}$

particularly noteworthy since in both this and previous studies it has been observed that various factors unaccounted for in this model, including conjugation site $e^{51}$ and protein surface charge, $^{53}$ affect bioconjugate ordering quality. The $95 \%$ confidence bounds on the predicted fwhm ${ }^{-1}$ value at $25 \mathrm{~nm}$ is $\pm 9 \mathrm{~nm}$, which is not high enough precision to distinguish between ordered and disordered phases within the approximate $\mathrm{fwhm}^{-1}$ range of $10-30 \mathrm{~nm} .{ }^{45}$ However, the precision of the model is sufficient to predict that conjugates with a predicted fwhm ${ }^{-1}$ below $10 \mathrm{~nm}$ will be disordered and those with a predicted fwhm ${ }^{-1}$ greater than $30 \mathrm{~nm}$ will self-assembled into ordered phases. Indeed, of the 10 conjugates from this study that fall outside the predicted $\mathrm{fwhm}^{-1}$ range of $10-30$ $\mathrm{nm}$, the model accurately assigns the ordering behavior of 9, only incorrectly predicting that the PhoA-PNIPAM conjugate will be disordered. All but one of the nonconstant variables in the model are statistically significant, and the positive coefficients associated with the linear molecular weight and $\% \beta$ sheet terms suggests that, holding other protein properties constant, larger proteins with a higher fraction of residues in $\beta$ sheets exhibit stronger ordering.

The ordering trends with molecular weight and $\beta$ sheet content can largely be rationalized by considering mobility and packing entropy within the protein domain. The irregularly shaped surfaces of proteins likely contribute to protein movement becoming frustrated at high concentration, resulting in a reduced mobility that inhibits self-assembly into wellordered structures. In terms of molecular weight, larger proteins tend to have a greater volume-to-surface area ratio, reducing the interfacial area between proteins within a given volume and thereby enhancing mobility. Protein mobility is also likely affected by entanglements within the polymer domains, however, as mobility should significantly decrease above the polymer entanglement molar mass. The combination of these two molecular weight effects may produce the Lorentzian-shaped peak in ordering quality around $28 \mathrm{kDa}$ (Figure 4), where proteins are large enough to avoid significant packing frustrations but are conjugated to PNIPAM of a sufficiently low molecular weight such that entanglements do not form. Additionally, proteins with a higher $\beta$ sheet content are more likely to contain $\beta$ sheets at the surface and therefore may be more likely to exhibit smoother, more regular surfaces, reducing packing frustrations between proteins. Indeed, mCherry, EGFP, and DFPase all have very high $\beta$ sheet content and display greater than expected ordering relative to a linear fit to molecular weight, whereas $\mathrm{HMb}$ and BSA each contain essentially no $\beta$ sheets (both are almost entirely composed of $\alpha$ helices) and exhibit weaker than expected ordering. Furthermore, even though both P450 and BSA have very similar low $\beta$ sheet content, only BSA is observed to form ordered lamellar phases presumably due to its larger molecular weight. Thus, this model based on only two protein properties accurately identified trends between these variables and bioconjugate $\mathrm{fwhm}^{-1}$ that can be used to predict the ordering quality of protein-polymer bioconjugates. As a result, the model provides important predictive design criteria that can be used to estimate whether a specific protein-polymer bioconjugate is likely to self-assemble before the conjugate is synthesized.

\section{CONCLUSIONS}

The self-assembly of 15 protein-PNIPAM bioconjugates was compared to provide insight into the factors affecting the quality of ordering and self-assembly behavior in proteinpolymer diblock copolymers. Many attributes of the phase behavior remain constant among all 15 bioconjugates. In each case, a transition from disordered to a disordered micellar phase is observed at low concentrations as temperature crosses the LCST of PNIPAM. In addition, increasing concentration in most of the conjugates leads to a disordered to ordered lyotropic transition.

However, this comparison also revealed differing phase behaviors in several of the proteins, such as a thermotropic ODT from a disordered phase into lamellar or hexagonal phases. Additionally, the $\beta$-barrel proteins mCherry and EGFP were found to have uniquely lower $\mathrm{C}_{\mathrm{ODT}} \mathrm{s}$ among the set, and only proteins with molar masses in the narrow range of roughly $20-36 \mathrm{kDa}$ were observed to exhibit hexagonally packed morphologies. Although the $\beta$-barrel proteins exhibited both the highest degree of ordering and the lowest $C_{\mathrm{ODT}}$ values, these two attributes were largely uncorrelated for the remainder of the proteins. Coupled with previous findings, these observations suggest that $C_{\mathrm{ODT}}$ and quality of ordering can be affected independently of one another.

Outside of the optimum molar mass range of $20-36 \mathrm{kDa}$, bioconjugate ordering generally improves with increasing molecular weight, as predicted by block copolymer selfassembly theories. Even very large bioconjugates, though, struggle to match the degree of ordering exhibited by bioconjugates of proteins within the optimum window, likely due to chain entanglement at high polymer molecular weight. These trends suggest that to optimize self-assembly in protein-PNIPAM bioconjugates, a balance must be made between increasing segregation strength from bioconjugate size while avoiding polymer entanglement to maintain species mobility.

A model constructed based on only protein molecular weight and $\%$ residues contained in $\beta$ sheets was able to capture $86 \%$ of the variation in $\mathrm{fwhm}^{-1}$ values across the studied bioconjugates and demonstrate good predictive capabilities. The model was demonstrated to provide an accurate prediction of whether a conjugate will form ordered phases for predicted fwhm ${ }^{-1}$ values outside the range of 10-30 $\mathrm{nm}$. While the model would benefit from a larger sample set of protein-polymer block copolymer SAXS data for further validation, the developed model suggests that certain aspects of protein architecture promote strong bioconjugate ordering. In particular, it suggests that likely candidates for forming wellordered protein-PNIPAM block copolymers would contain protein blocks that are either high molecular weight and have a large fraction of $\beta$ sheets or have a molecular weight within the range of $20-36 \mathrm{kDa}$. These insights should allow the selection and design of proteins with enhanced ordering quality when conjugated to PNIPAM, broadening the scope of proteins that can be used in functional self-assembled biomaterials. 


\section{ASSOCIATED CONTENT}

\section{S Supporting Information}

The Supporting Information is available free of charge on the ACS Publications website at DOI: 10.1021/acs.biomac.9b00768.

Gene sequences, protein sequences, GPC traces, SDSPAGE gels, CD traces, comparisons of $\mathrm{fwhm}^{-1}$ with various protein properties, calculation of entanglement molar mass, and ordering quality model development methodology (PDF)

\section{AUTHOR INFORMATION}

\section{Corresponding Author}

*B. D. Olsen. Telephone: 1-617-715-4548; E-mail: bdolsen@ mit.edu.

ORCID $\odot$

Allie C. Obermeyer: 0000-0003-2412-2021

Helen Yao: 0000-0001-7327-9979

Bradley D. Olsen: 0000-0002-7272-7140

\section{Notes}

The authors declare no competing financial interest.

\section{ACKNOWLEDGMENTS}

This work was supported by the Department of Energy Office of Basic Energy Sciences (award number DE-SC0007106). We thank Dr. Soenke Siefert for experimental assistance at APS beamline 12-ID-C, Dr. Christopher Tassone for assistance at SSRL beamline 1-5, and Dr. Chenhui Zhu for assistance at ALS beamline 7.3.3. We also thank Carolyn Mills and Dr. Xuehui Dong for assistance in sample preparation and collection of SAXS data. The Biophysical Instrumentation Facility for the Study of Complex Macromolecular Systems (NSF-0070319) is gratefully acknowledged for use of a CD spectrometer.

\section{REFERENCES}

(1) Kirk, O.; Borchert, T. V.; Fuglsang, C. C. Industrial enzyme applications. Curr. Opin. Biotechnol. 2002, 13 (4), 345-351.

(2) Minteer, S. D.; Liaw, B. Y.; COoney, M. J. Enzyme-based biofuel cells. Curr. Opin. Biotechnol. 2007, 18 (3), 228-234.

(3) Cracknell, J. A.; Vincent, K. A.; Armstrong, F. A. Enzymes as working or inspirational electrocatalysts for fuel cells and electrolysis. Chem. Rev. 2008, 108 (7), 2439-2461.

(4) Cogdell, R. J.; Gall, A.; Köhler, J. The architecture and function of the light-harvesting apparatus of purple bacteria: from single molecules to in vivo membranes. Q. Rev. Biophys. 2006, 39 (03), 227-324.

(5) Duran, N.; Esposito, E. Potential applications of oxidative enzymes and phenoloxidase-like compounds in wastewater and soil treatment: a review. Appl. Catal., B 2000, 28 (2), 83-99.

(6) Karam, J.; Nicell, J. A. Potential applications of enzymes in waste treatment. J. Chem. Technol. Biotechnol. 1997, 69 (2), 141-153.

(7) Cowell, D.; Dowman, A.; Ashcroft, T.; Caffoor, I. The detection and identification of metal and organic pollutants in potable water using enzyme assays suitable for sensor development. Biosens. Bioelectron. 1995, 10 (6-7), 509-516.

(8) Russell, A. J.; Berberich, J. A.; Drevon, G. F.; Koepsel, R. R. Biomaterials for Mediation of Chemical and Biological Warfare Agents. Annu. Rev. Biomed. Eng. 2003, 5, 1-27.

(9) Guiseppi-Elie, A.; Lei, C.; Baughman, R. H. Direct electron transfer of glucose oxidase on carbon nanotubes. Nanotechnology 2002, 13 (5), 559.

(10) Wooten, M.; Karra, S.; Zhang, M.; Gorski, W. On the Direct Electron Transfer, Sensing, and Enzyme Activity in the Glucose
Oxidase/Carbon Nanotubes System. Anal. Chem. 2014, 86 (1), 752757.

(11) Kumar, N.; Parajuli, O.; Hahm, J. I. Two-dimensionally selfarranged protein nanoarrays on diblock copolymer templates. J. Phys. Chem. B 2007, 111 (17), 4581-4587.

(12) Fan, X.; Yun, S.-H. The potential of optofluidic biolasers. Nat. Methods 2014, 11 (2), 141.

(13) Ta, V. D.; Caixeiro, S.; Fernandes, F. M.; Sapienza, R. Microsphere Solid-State Biolasers. Adv. Opt. Mater. 2017, 5 (8), 1601022.

(14) Cantone, S.; Hanefeld, U.; Basso, A. Biocatalysis in nonconventional media-ionic liquids, supercritical fluids and the gas phase. Green Chem. 2007, 9 (9), 954-971.

(15) Katchalski-Katzir, E. Immobilized enzymes-learning from past successes and failures. Trends Biotechnol. 1993, 11 (11), 471-478.

(16) Mateo, C.; Palomo, J. M.; Fernandez-Lorente, G.; Guisan, J. M.; Fernandez-Lafuente, R. Improvement of enzyme activity, stability and selectivity via immobilization techniques. Enzyme Microb. Technol. 2007, 40 (6), 1451-1463.

(17) Guzik, U.; Hupert-Kocurek, K.; Wojcieszyńska, D. Immobilization as a strategy for improving enzyme properties-application to oxidoreductases. Molecules 2014, 19 (7), 8995-9018.

(18) Fernandez-Lafuente, R. Stabilization of multimeric enzymes: Strategies to prevent subunit dissociation. Enzyme Microb. Technol. 2009, 45 (6-7), 405-418.

(19) Balcão, V. M.; Vila, M. M. Structural and functional stabilization of protein entities: state-of-the-art. Adv. Drug Delivery Rev. 2015, 93, 25-41.

(20) Datta, S.; Christena, L. R.; Rajaram, Y. R. S. Enzyme immobilization: an overview on techniques and support materials. 3 Biotech 2013, 3 (1), 1-9.

(21) Rodrigues, R. C.; Ortiz, C.; Berenguer-Murcia, Á.; Torres, R.; Fernández-Lafuente, R. Modifying enzyme activity and selectivity by immobilization. Chem. Soc. Rev. 2013, 42 (15), 6290-6307.

(22) Zhou, Z.; Hartmann, M. Progress in enzyme immobilization in ordered mesoporous materials and related applications. Chem. Soc. Rev. 2013, 42 (9), 3894-3912.

(23) Bonanno, L. M.; DeLouise, L. A. Steric crowding effects on target detection in an affinity biosensor. Langmuir 2007, 23 (10), $5817-5823$

(24) Miller, R.; Bartha, R. Evidence from liposome encapsulation for transport-limited microbial metabolism of solid alkanes. Appl. Environ. Microbiol. 1989, 55 (2), 269-274.

(25) Stein, E. W.; Grant, P. S.; Zhu, H.; McShane, M. J. Microscale enzymatic optical biosensors using mass transport limiting nanofilms. 1. Fabrication and characterization using glucose as a model analyte. Anal. Chem. 2007, 79 (4), 1339-1348.

(26) Hernandez, K.; Fernandez-Lafuente, R. Control of protein immobilization: coupling immobilization and site-directed mutagenesis to improve biocatalyst or biosensor performance. Enzyme Microb. Technol. 2011, 48 (2), 107-122.

(27) Lu, B.; Smyth, M. R.; O’Kennedy, R. Tutorial review. Oriented immobilization of antibodies and its applications in immunoassays and immunosensors. Analyst 1996, 121 (3), 29R-32R.

(28) Cai, Y.; Ocko, B. M. Large-scale fabrication of protein nanoarrays based on nanosphere lithography. Langmuir 2005, 21 (20), 9274-9279.

(29) Maury, P.; Escalante, M.; Péter, M.; Reinhoudt, D. N.; Subramaniam, V.; Huskens, J. Creating Nanopatterns of His-Tagged Proteins on Surfaces by Nanoimprint Lithography Using Specific NiNTA-Histidine Interactions. Small 2007, 3 (9), 1584-1592.

(30) Nam, J.-M.; Han, S. W.; Lee, K.-B.; Liu, X.; Ratner, M. A.; Mirkin, C. A. Bioactive Protein Nanoarrays on Nickel Oxide Surfaces Formed by Dip-Pen Nanolithography. Angew. Chem., Int. Ed. 2004, 43 (10), 1246-1249.

(31) Kim, B.; Lam, C. N.; Olsen, B. D. Nanopatterned Protein Films Directed by Ionic Complexation with Water-Soluble Diblock Copolymers. Macromolecules 2012, 45 (11), 4572-4580. 
(32) Kumar, N.; Hahm, J.-i. Nanoscale protein patterning using selfassembled diblock copolymers. Langmuir 2005, 21 (15), 6652-6655.

(33) Bates, F. S. Polymer-Polymer Phase Behavior. Science 1991, 251 (4996), 898-905.

(34) Bates, F. S.; Fredrickson, G. H. Block Copolymers-Designer Soft Materials. Phys. Today 1999, 52, 32.

(35) Boyer, C.; Bulmus, V.; Liu, J.; Davis, T. P.; Stenzel, M. H.; Barner-Kowollik, C. Well-Defined Protein-Polymer Conjugates via in Situ RAFT Polymerization. J. Am. Chem. Soc. 2007, 129 (22), 71457154.

(36) De, P.; Li, M.; Gondi, S. R.; Sumerlin, B. S. TemperatureRegulated Activity of Responsive Polymer-Protein Conjugates Prepared by Grafting-from via RAFT Polymerization. J. Am. Chem. Soc. 2008, 130 (34), 11288-11289.

(37) Lele, B. S.; Murata, H.; Matyjaszewski, K.; Russell, A. J. Synthesis of Uniform Protein-Polymer Conjugates. Biomacromolecules 2005, 6 (6), 3380-3387.

(38) Boerakker, M. J.; Botterhuis, N. E.; Bomans, P. H. H.; Frederik, P. M.; Meijer, E. M.; Nolte, R. J. M.; Sommerdijk, N. A. J. M. Aggregation Behavior of Giant Amphiphiles Prepared by Cofactor Reconstitution. Chem. - Eur. J. 2006, 12 (23), 6071-6080.

(39) Chang, D.; Huang, A.; Olsen, B. D. Kinetic Effects on SelfAssembly and Function of Protein-Polymer Bioconjugates in Thin Films Prepared by Flow Coating. Macromol. Rapid Commun. 2017, 38 (1), 1600449

(40) Lam, C. N.; Olsen, B. D. Phase transitions in concentrated solution self-assembly of globular protein-polymer block copolymers. Soft Matter 2013, 9 (8), 2393-2402.

(41) Lavigueur, C.; Garcia, J. G.; Hendriks, L.; Hoogenboom, R.; Cornelissen, J. J. L. M.; Nolte, R. J. M. Thermoresponsive giant biohybrid amphiphiles. Polym. Chem. 2011, 2 (2), 333-340.

(42) Thomas, C. S.; Glassman, M. J.; Olsen, B. D. Solid-State Nanostructured Materials from Self-Assembly of a Globular ProteinPolymer Diblock Copolymer. ACS Nano 2011, 5 (7), 5697-5707.

(43) Dong, X. H.; Obermeyer, A. C.; Olsen, B. D. ThreeDimensional Ordered Antibody Arrays Through Self-Assembly of Antibody-Polymer Conjugates. Angew. Chem., Int. Ed. 2017, 56 (5), 1273-1277.

(44) Huang, A.; Qin, G.; Olsen, B. D. Highly Active Biocatalytic Coatings from Protein-Polymer Diblock Copolymers. ACS Appl. Mater. Interfaces 2015, 7 (27), 14660-14669.

(45) Paloni, J. M.; Miller, E. A.; Sikes, H. D.; Olsen, B. D. Improved Ordering in Low Molecular Weight Protein-Polymer Conjugates Through Oligomerization of the Protein Block. Biomacromolecules 2018, 19 (9), 3814-3824.

(46) Glotzer, S. C.; Horsch, M. A.; Iacovella, C. R.; Zhang, Z.; Chan, E. R.; Zhang, X. Self-assembly of anisotropic tethered nanoparticle shape amphiphiles. Curr. Opin. Colloid Interface Sci. 2005, 10 (5), 287-295.

(47) Damasceno, P. F.; Engel, M.; Glotzer, S. C. Predictive selfassembly of polyhedra into complex structures. Science 2012, 337 (6093), 453-457.

(48) Chang, D.; Lam, C. N.; Tang, S.; Olsen, B. D. Effect of polymer chemistry on globular protein-polymer block copolymer self-assembly. Polym. Chem. 2014, 5 (17), 4884-4895.

(49) Chang, D.; Olsen, B. D. Self-assembly of protein-zwitterionic polymer bioconjugates into nanostructured materials. Polym. Chem. 2016, 7 (13), 2410-2418.

(50) Qin, G.; Glassman, M. J.; Lam, C. N.; Chang, D.; Schaible, E.; Hexemer, A.; Olsen, B. D. Topological Effects on Globular ProteinELP Fusion Block Copolymer Self-Assembly. Adv. Funct. Mater. 2015, 25 (5), 729-738.

(51) Huang, A.; Olsen, B. D. Self-Assembly of Differently Shaped Protein-Polymer Conjugates through Modification of the Bioconjugation Site. Macromol. Rapid Commun. 2016, 37 (15), 1268-1274.

(52) Lam, C. N.; Kim, M.; Thomas, C. S.; Chang, D.; Sanoja, G. E.; Okwara, C. U.; Olsen, B. D. The Nature of Protein Interactions Governing Globular Protein-Polymer Block Copolymer SelfAssembly. Biomacromolecules 2014, 15 (4), 1248-1258.
(53) Lam, C. N.; Yao, H.; Olsen, B. D. The Effect of Protein Electrostatic Interactions on Globular Protein-Polymer Block Copolymer Self-Assembly. Biomacromolecules 2016, 17 (9), 28202829 .

(54) Blum, M.-M.; Löhr, F.; Richardt, A.; Rüterjans, H.; Chen, J. C.$\mathrm{H}$. Binding of a designed substrate analogue to diisopropyl fluorophosphatase: implications for the phosphotriesterase mechanism. J. Am. Chem. Soc. 2006, 128 (39), 12750-12757.

(55) Scolnick, L. R.; Christianson, D. W. X-ray crystallographic studies of alanine-65 variants of carbonic anhydrase II reveal the structural basis of compromised proton transfer in catalysis. Biochemistry 1996, 35 (51), 16429-16434.

(56) Grüning, N.-M.; Du, D.; Keller, M. A.; Luisi, B. F.; Ralser, M. Inhibition of triosephosphate isomerase by phosphoenolpyruvate in the feedback-regulation of glycolysis. Open Biol. 2014, 4 (3), 130232.

(57) Baumann, H.; Knapp, S.; Lundback, T.; Ladenstein, R.; Hard, T. Solution structure and DNA-binding properties of a thermostable protein from the archaeon Sulfolobus solfataricus. Nat. Struct. Biol. 1994, 1 (11), 808-19.

(58) Vojtechovsky, J.; Chu, K.; Berendzen, J.; Sweet, R. M.; Schlichting, I. Crystal structures of myoglobin-ligand complexes at near-atomic resolution. Biophys. J. 1999, 77 (4), 2153-74.

(59) Shu, X.; Shaner, N. C.; Yarbrough, C. A.; Tsien, R. Y.; Remington, S. J. Novel chromophores and buried charges control color in mFruits. Biochemistry 2006, 45 (32), 9639-47.

(60) Royant, A.; Noirclerc-Savoye, M. Stabilizing role of glutamic acid 222 in the structure of Enhanced Green Fluorescent Protein. J. Struct. Biol. 2011, 174 (2), 385-90.

(61) Fox, J. M.; Kang, K.; Sastry, M.; Sherman, W.; Sankaran, B.; Zwart, P. H.; Whitesides, G. M. Water-Restructuring Mutations Can Reverse the Thermodynamic Signature of Ligand Binding to Human Carbonic Anhydrase. Angew. Chem., Int. Ed. 2017, 56 (14), 38333837.

(62) Davenport, R. C.; Bash, P. A.; Seaton, B. A.; Karplus, M.; Petsko, G. A.; Ringe, D. Structure of the triosephosphate isomerasephosphoglycolohydroxamate complex: an analogue of the intermediate on the reaction pathway. Biochemistry 1991, 30 (24), 5821-6.

(63) Elias, M.; Liebschner, D.; Koepke, J.; Lecomte, C.; Guillot, B.; Jelsch, C.; Chabriere, E. Hydrogen atoms in protein structures: highresolution X-ray diffraction structure of the DFPase. BMC Res. Notes 2013, 6, 308

(64) Peck, A.; Sunden, F.; Andrews, L. D.; Pande, V. S.; Herschlag, D. Tungstate as a Transition State Analog for Catalysis by Alkaline Phosphatase. J. Mol. Biol. 2016, 428 (13), 2758-68.

(65) Williams, P. A.; Cosme, J.; Vinkovic, D. M.; Ward, A.; Angove, H. C.; Day, P. J.; Vonrhein, C.; Tickle, I. J.; Jhoti, H. Crystal structures of human cytochrome P450 3A4 bound to metyrapone and progesterone. Science 2004, 305 (5684), 683-6.

(66) Majorek, K. A.; Porebski, P. J.; Dayal, A.; Zimmerman, M. D.; Jablonska, K.; Stewart, A. J.; Chruszcz, M.; Minor, W. Structural and immunologic characterization of bovine, horse, and rabbit serum albumins. Mol. Immunol. 2012, 52 (3-4), 174-82.

(67) Harris, L. J.; Larson, S. B.; Hasel, K. W.; McPherson, A. Refined structure of an intact IgG2a monoclonal antibody. Biochemistry 1997, 36 (7), 1581-97.

(68) Voss, N. R.; Gerstein, M. 3V: cavity, channel and cleft volume calculator and extractor. Nucleic Acids Res. 2010, 38 (suppl_2), W555-W562.

(69) Willard, L.; Ranjan, A.; Zhang, H.; Monzavi, H.; Boyko, R. F.; Sykes, B. D.; Wishart, D. S. VADAR: a web server for quantitative evaluation of protein structure quality. Nucleic Acids Res. 2003, 31 (13), 3316-3319.

(70) De Gennes, P.-G. Scaling concepts in polymer physics; Cornell University Press, 1979.

(71) Leibler, L. Theory of Microphase Separation in Block Copolymers. Macromolecules 1980, 13 (6), 1602-1617.

(72) Matsen, M. W.; Schick, M. Stable and unstable phases of a diblock copolymer melt. Phys. Rev. Lett. 1994, 72 (16), 2660-2663. 
(73) Cai, L.-H.; Panyukov, S.; Rubinstein, M. Hopping Diffusion of Nanoparticles in Polymer Matrices. Macromolecules 2015, 48 (3), 847-862.

(74) Lee, L. T.; Jean, B.; Menelle, A. Effect of Temperature on the Adsorption of Poly(N-isopropylacrylamide) at the Air-Solution Interface. Langmuir 1999, 15 (9), 3267-3272.

(75) Olsen, B. D.; Segalman, R. A. Self-assembly of rod-coil block copolymers. Mater. Sci. Eng., R 2008, 62 (2), 37-66.

(76) Thomas, C. S.; Olsen, B. D. Coil fraction-dependent phase behaviour of a model globular protein-polymer diblock copolymer. Soft Matter 2014, 10 (17), 3093-3102. 